\title{
FILTER KALMAN UNTUK ESTIMASI DAYA PADA KOMUNIKASI BERGERAK
}

\author{
Rini Puji Astutik \\ astutik_rpa@umg.ac.id
}

\section{Program Studi Teknik Elektro Universitas Muhammadiyah Gresik}

\begin{abstract}
Abstrak
Dalam Komunikasi bergerak, keakuratan estimasi daya lokal rata-rata (Shadow) pada mobile station sangat penting kegunaannya seperti dalam pengontrolan daya, hal ini karena berfluktuatifnya daya terima mobile station.

Pada Penelitian ini akan dibahas Filter Kalman skalar untuk estimasi daya lokal rata-rata (Shadow) dengan perhitungan yang sedikit komplek. Untuk menganalisis kemampuan filter Kalman digunakan perbandingan melalui analisis "Mean Square Error" dengan estimator lain yaitu Sample Average.

Dari analisa menunjukkan hasil bahwa filter Kalman hampir dalam semua kondisi selalu mempunyai unjuk kerja lebih bagus dibanding estimator Sample Average. Dimana unjuk kerja estimator Sample Average akan menurun dengan cepat ketika ukuran window menyimpang melebihi range tertentu.
\end{abstract}

Kata kunci : filter kalman, komunikasi bergerak.

\section{PENDAHULUAN}

Seiring dengan meningkatnya pendapatan masyarakat dan mobilitas yang tinggi, menyebabkan berpindahnya trend sistem komunikasi dari yang fixed ke mobile. Sistem komunikasi bergerak tidak terlepas dari adanya fenomena alam yaitu fading. Dengan adanya fading dan pergerakan mobile station menyebabkan daya yang diterima mobile station berfluktuatif sehingga diperlukan estimasi dan prediksi dari daya lokal rata-rata yang akurat. Hal ini yang melatarbelakangi penulis untuk menyusun penelitian ini.

Timbul suatu permasalahan dimana saat ini banyak dari sistem komunikasi bergerak komersial menggunakan estimator Sample Average yang mempunyai unjuk kerja bertambah baik pada range window tertentu dan memburuk saat melebihi range tersebut. Kemudian permasalahan dibatasi dengan menganggap daya mobile station yang dibentuk dari 2 macam fading diasumsikan tidak berkorelasi.

Dalam penelitian ini akan dibahas suatu estimator berdasar filter Kalman yang bertujuan untuk mengestimasi daya pada komunikasi bergerak terutama estimasi daya lokal rata-rata dengan perhitungan yang sedikit komplek melalui analisa "Mean Square Error" (MSE). Dan juga menyelidiki bagaimana unjuk kerja filter Kalman jika dibanding dengan estimator Sample Average.

\section{PEMODELAN SISTEM ESTIMASI}

\subsection{Sistem Estimasi}

Dalam persoalan estimasi yang biasa kita jumpai terdapat 3 jenis yaitu filtering, smoothing dan prediction. Dalam penelitian ini proses estimasi ditekankan pada jenis filtering yaitu apabila saat estimasi diinginkan bertepatan dengan waktu saat pengukuran terakhir

Sistem estimasi dengan berdasar filter Kalman dapat digambarkan seperti gambar 2.1 dimana daya terima sebelumnya dipengaruhi oleh small scale fading (Multipath) yaitu fluktuasi daya yang cepat pada skala kecil dikarenakan pantulan lintasan jamak suatu gelombang transmisi oleh penghambur lokal seperti rumah-rumah, gedung-gedung dan bangunan lain atau oleh halangan lain seperti hutan (pepohonan) yang mengelilingi suatu mobile station yang bergerak tetapi tidak oleh gunung atau bukit yang terletak diantara lokasi base station dan mobile station. dan large scale fading (Shadowing) yaitu fluktuasi daya yang lambat pada path loss skala besar dikarenakan oleh obstacle dalam lintasan propagasi antara mobile station dan base station. 


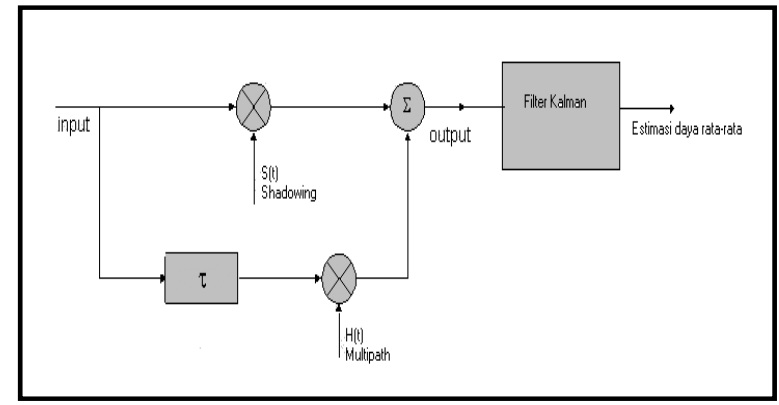

Gambar 2.1 Sistem estimasi filter Kalman

\subsection{Pemodelan Sistem Estimasi}

Sebelum masuk ke pemodelan sistem perlu dijelaskan sedikit tentang notasi yang akan dipergunakan sistem dalam penelitian ini sebagai berikut.

- Notasi $\log ($.$) melambangkan logaritma berbasis 10$.

- $\ln ($.$) melambangkan logarima berbasis e.$

- $\quad$ E[.] melambangkan ekspektasi secara matematis untuk semua variable random didalam kurung.

- $\mathrm{r}_{\mathrm{x}(\mathrm{t})}:=\mathrm{E}[\mathrm{x}(\mathrm{t}) \mathrm{x}(\mathrm{t}+\tau)]$ melambangkan fungsi autokorelasi.

- $\quad c_{x}(\tau):=r_{x}(\tau)-(E[x(t)])^{2}$ melambangkan fungsi kovarian pada $\tau$

Model perkalian yang banyak digunakan untuk daya yang diterima $\mathrm{p}(\mathrm{t})$ pada mobile station untuk sistem komuniksi bergerak diberikan

$$
\mathrm{p}(\mathrm{t})=|\mathrm{h}(\mathrm{t})|^{2} \mathrm{~s}(\mathrm{t})
$$

dimana $|\mathrm{h}(\mathrm{t})|^{2}$ adalah fluktuasi daya yang cepat yang disebabkan oleh Multipath, s(t) adalah fluktuasi daya yang lambat yang dikarenakan oleh Shadowing dan kedua proses tersebut diasumsikan Statistically Independent. Pada umumnya jika $\mathrm{E}\left[|\mathrm{h}(\mathrm{t})|^{2}\right]$ adalah konstan, kemudian terserap dalam $\mathrm{s}(\mathrm{t})$ sehingga dapat diasumsikan bahwa $\mathrm{E}\left[|\mathrm{h}(\mathrm{t})|^{2}\right]=1$ untuk penyederhanaan.

Untuk lebih menyederhanakan dalam sistem digital, pengukuran daya dibentuk dalam decibel $(\mathrm{dB})$ yang memperbolehkan jangkauan dinamik yang lebar dari level daya. Hubungan model domain logaritma diperoleh dari persamaan (2.1) adalah

$$
\mathrm{P}(\mathrm{t})=\mathrm{S}(\mathrm{t})+\mathrm{H}(\mathrm{t})
$$

Dimana $P(t)=10 \log [p(t)], S(t)=10 \log [s(t)]$, dan $H(t)=10 \log \left[|h(t)|^{2}\right]$. Fokus dari penelitian ini adalah pada model terakhir dikarenakan kebanyakan dari sistem seperti kontrol daya yang mengandalkan pada perkiraan dari daya shadow dalam dB.

Permasalahan kemudian dapat dirumuskan sebagai berikut Diberikan $\{P(t)\}_{t=0}^{t_{0}}$ untuk mengestimasi $S\left(t_{0}\right)$. Dalam domain waktu diskrit, kita ingin memperkirakan $\mathrm{S}(\mathrm{n})=\mathrm{S}(\mathrm{nTs})$ dalam basis dari $\mathrm{P}(\mathrm{i})=\mathrm{P}(\mathrm{iT}), \mathrm{i}=0,1, \ldots \mathrm{n}$ dimana $\mathrm{Ts}$ adalah periode sampling.

Untuk menyelesaikan permasalahan, dibutuhkan harga statistik dari $\mathrm{h}(\mathrm{t})$ dan $\mathrm{S}(\mathrm{t})$. Dalam prakteknya model berikut dari multipath $\mathrm{h}(\mathrm{t})$ biasanya dipakai

$\mathrm{h}(\mathrm{t})=\lim _{R \rightarrow \infty} \frac{1}{R} \sum_{r=1}^{R} b_{1} e^{j\left(\omega_{D} \cos \left(\theta_{r}\right) t+\phi_{r}\right)}$

dimana $\omega_{\mathrm{D}}=2 \pi \mathrm{v} / \lambda$ adalah penyebaran Doppler, $\lambda$ adalah panjang gelombang yang berkaitan dengan frekuensi carrier, $\mathrm{v}$ adalah magnitude dari kecepatan pada mobile station, $\mathrm{R}$ adalah angka dari independent scatterers (biasanya $\mathrm{R}=20$ sudah cukup untuk memberikan pendekatan yang bagus) $\mathrm{b}_{\mathrm{r}}$ adalah gain, $\left\{\theta_{r}\right\}_{r=1}^{R}$ adalah sudut antara gelombang datang dan antena mobile station diasumsikan berdistribusi uniform $(-\pi, \pi)$ dan $\left\{\phi_{r}\right\}_{r=1}^{R}$ variable acak phase, juga berdistribusi uniform $(-\pi, \pi)$.

Hal ini dapat ditunjukkan bahwa model persamaan (2.3) dapat secara tidak langsung dinyatakan berdistribusi Reyleigh dan pdf dari $\mathrm{H}(\mathrm{t})$ diberikan oleh 
$f_{H}=\frac{\ln (10)}{10} \exp \left(\frac{\ln (10)}{10} x-\exp \left(\frac{\ln (10)}{10} x\right)\right)$

Rata-rata dari $\mathrm{H}(\mathrm{t})$ dapat dihitung dari persamaan (2.4) sebagai berikut

$\bar{H}=\mathrm{E}[H(t)]=\frac{10 \gamma}{\ln (10)}$

dimana $\gamma=0.577216 \ldots$ adalah konstanta euler .

Dengan menggunakan persamaan (2.3) diperoleh covarian dari $\mathrm{H}(\mathrm{t})$ sebagai berikut

$c_{H}(\tau)=\mathrm{E}[H(t+\tau) H(t)]-\bar{H}^{2}=\left(\frac{10}{\ln (10)}\right)^{2} \sum_{k=1}^{\infty} \frac{J_{0}^{2 k}(\omega D \tau)}{k^{2}}$

dimana $\mathbf{J}_{0}$ adalah fungsi Bessel jenis pertama orde nol dan varian $\mathrm{H}(\mathrm{t})$ kemudian diperoleh saat $\tau=$ 0 sebagai berikut $\sigma_{\mathrm{H}}^{2}=[10 / \ln (10)]^{2}\left(\pi^{2} / 6\right)$. Meskipun persamaan (2.6) hanya disarankan untuk proses sample multipath $\left(\mathrm{H}_{\mathrm{nT}}\right)$ ) yang diasumsikan mendekati tidak berkorelasi terhadap periode sampling $\mathrm{T}_{\mathrm{s}}$ yang relarif besar.

Asumsi yang lebih kuat berikut ini biasa dipakai.

- Asumsi A: proses sample Multipath $\left(\mathrm{H}_{(\mathrm{nT}}\right)$ ) diberikan persamaan (2.4) dan independent terhadap proses Shadow $\mathrm{S}\left(\mathrm{nT}_{\mathrm{s}}\right)$

Satu dari dua asumsi alternatif biasanya dipakai untuk proses Shadow

- Asumsi B: Proses Shadow S(n) adalah konstan selama window tertentu.

- Asumsi C: Proses Shadow S(n) mengikuti model autoregressive (AR) orde pertama .

Dalam prakteknya asumsi $\mathrm{C}$ lebih realistis dan termasuk dalam asumsi $\mathrm{B}$, sebab $\mathrm{S}(\mathrm{t})$ konstan dapat dianggap sebagai kasus yang ekstrim dari model AR setara untuk koefisien $a=1$ dan $\sigma_{\mathrm{s}}=0$.

Model auto regressive orde pertama (AR (1)) untuk proses Shadow, fungsi autokovarian dari $\mathrm{S}(\mathrm{t})$ dalam daerah urban dan suburban adalah sebagai berikut

$c_{s}(\tau)=\sigma_{s}^{2} \exp \left(-v \mathrm{I} \tau \mathrm{I} / X_{c}\right)$

dimana $\sigma_{\mathrm{S}}$ melambangkan varian shadow dan $\mathrm{X}_{\mathrm{c}}$ adalah jarak efektif korelasi yang merupakan kunci atribut daerah wireless. Dimana $\mathrm{X}_{\mathrm{c}}$ didapat seperti ditunjukan pada

$$
X_{C}=-\frac{D}{\ln \left(\varepsilon_{D}\right)} \geq 0
$$

dimana $\varepsilon_{\mathrm{D}}$ adalah koefisien korelsi dari proses shadow antara 2 titik yang berjarak D. $\mathrm{X}_{\mathrm{c}}$ biasanya dalam range antara $10 \mathrm{~m}$ (daerah urban) dan $500 \mathrm{~m}$ (daerah suburban). Nilai $\sigma_{\mathrm{S}}$ juga tergantung pada lingkungan. Dalam daerah suburban nilai typicalnya $8 \mathrm{~dB}$ sementara dalam lingkungan urban kira-kira $4 \mathrm{~dB}$

Model AR(1) untuk proses Shadow diperoleh sebagai berikut

$\mathrm{S}(\mathrm{n})=a \mathrm{~S}(\mathrm{n}-1)+\phi(\mathrm{n})$

Dimana $\mathrm{S}(\mathrm{n})=\mathrm{S}\left(\mathrm{nT}_{\mathrm{s}}\right), \quad \phi(\mathrm{n})$ adalah noise white Gaussian dengan mean nol dan varian $\sigma_{\phi}^{2}=\left(1-a^{2}\right) \sigma_{S}^{2}$ dan $\mathrm{S}[0] \sim N\left(\mu_{\mathrm{s}}, \sigma_{s}^{2}\right)$. Koefisien $a$ diperoleh sebagai berikut

$$
a=\exp \left(-\mathrm{vT}_{\mathrm{s}} / \mathrm{X}_{\mathrm{c}}\right)
$$

kemudian pada ${ }^{1}$ diperoleh

$$
\begin{gathered}
\mathrm{E}[\mathrm{S}(\mathrm{n})]=a^{\mathrm{n}} \mu_{\mathrm{S}} \\
c_{S}(n+k, n)=a^{2 n+k} \sigma_{S}^{2}+\sigma_{\phi}^{2} a^{k} \sum_{l=0}^{n-1} a^{2 l}, \ldots k \geq 0 \\
\operatorname{Var}(S(n))=c_{S}(n, n)=a^{2 n} \sigma_{S}^{2} \sum_{l=0}^{n-1} a^{2 l} \ldots \ldots \ldots \ldots
\end{gathered}
$$

Dapat dicatat bahwa mean E[S(n)] turun secara monoton saat n naik. Parameter $\operatorname{diset}\left(\sigma_{S}^{2}, \mathrm{~T}_{\mathrm{s}}, \mathrm{v}, \mathrm{X}_{\mathrm{c}}\right)$ mendifinisikan proses Shadow secara statistik orde 2. Untuk penyederhanaan kita asumsikan bahwa $\mu_{\mathrm{s}}=0$ kemudian

$$
\mathrm{E}[\mathrm{S}(\mathrm{n})]=0
$$

Saat $\mathrm{n} \rightarrow \infty$ didapatkan

$c_{S}(n+k, n) \rightarrow \sigma_{S}^{2} a^{k}=c_{S}(k)=r_{S}(k), \ldots . . . k \geq 0$

${ }^{1}$ S. M. Kay,"Fundamentals of Statistical Signal Processing". EnglewoodCliffs, NJ: Prentice-Hall, 1993, vol. 1.hal. 422-423 


\section{PROSES ESTIMASI DAYA PADA KOMUNIKASI BERGERAK}

\subsection{Pendahuluan}

Berikut ini akan dijelaskan bagaimana proses estimasi dilakukan berdasarkan pemodelan sistem yang telah diuraikan sebelumnya baik untuk estimator Sample Average yang sebagai pembanding maupun estimator filter Kalman sendiri.

Proses estimasi baik untuk Sample Average maupun filter Kalman mengambil asumsi untuk dua daerah yang berbeda yaitu daerah urban dan suburban dimana diasumsikan mobile station bergerak dengan kecepatan konstan yaitu $20 \mathrm{Km}$ jam. Untuk daerah urban diambil harga $\sigma_{S}=4 \mathrm{~dB}$, jarak efektif korelasi $\mathrm{Xc}=10 \mathrm{~m}$, sedang untuk daerah suburban diambil harga $\sigma_{\mathrm{S}}=10 \mathrm{~dB}$, jarak efektif korelasi $\mathrm{Xc}=500 \mathrm{~m}$. Sedangkan periode sampling yang digunakan adalah $\mathrm{T}_{\mathrm{s}}=0,054$ detik untuk periode sampling yang besar, $\mathrm{T}_{\mathrm{s}}=0,01$ detik untuk periode sampling yang kecil, dan $\mathrm{T}_{\mathrm{s}}=0,001$ detik untuk periode sampling yang sangat kecil. Selain itu juga dengan mempertimbangkan perubahan kecepatan mobile station dari $20 \mathrm{Km}$ jam sampai $80 \mathrm{Km}$ ljam khusus untuk filter Kalman yang akan dibandingkan dengan tanpa mempertimbangkan perubahan kecepatan tersebut.

Dari asumsi yang ada untuk daerah urban koefisien $a=0,9704$ saat $\mathrm{T}_{\mathrm{s}}=0,054$ detik, dan 0,9945 untuk $\mathrm{T}_{\mathrm{s}}=0,01$ detik. Dan pada daerah suburban $a=0,9998$ saat $\mathrm{T}_{\mathrm{s}}=0,054$ detik.

\subsection{Estimtor Sample Average}

Estimator Sample Average adalah suatu estimator berdasar window. Estimator ini bekerja bagus dengan anggapan bahwa proses shadow adalah konstan selama window rata-rata, dalam hal ini unjuk kerja meningkat saat ukuran window bertambah.

\subsubsection{Model Estimasi pada Estimator Sample Average}

Dalam asumsi A dan B estimator Sample average bekerja bagus tetapi perlu dicatat bahwa kedua asumsi menetapkan syarat-syarat yang bertentangan dalam prakteknya, karena membuat $\mathrm{T}_{\mathrm{s}}$ besar berlawanan dengan asumsi dari proses shadow yang konstan. Ketika proses shadow bervariasi ikut diperhitungkan, unjuk kerja dari estimator ini sangat memburuk ketika ukuran window bertambah melebihi nilai tertentu.

Untuk membanding estimator Sample Average dan estimator filter Kalman maka proses Shadow secara praktis mengikuti model AR(1) sehingga didapat Least Square Error (LSE) sebagai berikut

$$
L S E=\frac{1}{L} \sum_{n=1}^{L}[S(n)-\hat{S}(n)]^{2}
$$

Sebagai kriteria unjuk kerja, dimana $\hat{S}(n)$ adalah estimator dari S(n) dan L adalah total sample ( $\mathrm{L} \neq$ ukuran window $\mathrm{N}$ ).

Untuk estimator Sample Average, secara teori diperoleh sebagai berikut

$\operatorname{Lim}_{L \rightarrow \infty} E[L S E]=\sigma_{s}^{2}\left[\frac{N-1}{N}-\frac{2}{N^{2}} \frac{a-N a^{N}+(N-1) a^{N+1}}{(1-a)^{2}}\right]+\frac{c_{H}(0)}{N}+2 \sum_{i=1}^{N-1}\left(\frac{N-i}{N^{2}}\right) \cdot c_{H}\left(i T_{s}\right)$

dimana $\mathrm{N}$ adalah ukuran window.

\subsubsection{Proses Estimasi pada Estimator Sample Average}

Pada estimator Sample Average ini untuk memudahkan pengamatan diambil ukuran window $\mathrm{N}$ yang berbeda untuk daerah urban dan suburban. Pada daerah urban diambil $\mathrm{N}=2$ sampai $\mathrm{N}=27$, sedangkan untuk daerah suburban diambil $\mathrm{N}=9$ sampai $\mathrm{N}=81$.

Kemudian dengan asumsi yang ada dan persamaan (3.1) yang merupakan unjuk kerja Sample Average juga ukuran window yang diambil diperoleh grafik yang menunjukkan bagaimana unjuk kerja dari Sample Average. Unjuk kerja ini yang akan menjadi pembanding dari estimator berdasar filter Kalman.

\subsection{Estimator Filter Kalman}

Berdasarkan model AR(1) untuk proses shadow S(t), filter Kalman skalar berdasarkan pendekatan untuk estimasi daya lokal dari sinyal yang diganggu oleh noise white Gaussian dimana sinyal dikarakteristikkan oleh model Auto Regressive yang dinamikal dengan white Gaussian sebagai pegendali noise. 


\subsubsection{Model Estimasi pada Filter Kalman}

Filter Kalman skalar diringkas dalam table 3.1, dimana estimator dari $\mathrm{S}(\mathrm{n})$ berdasarkan $\{P(i)\}_{j=0}^{n}$ dilambangkan sebagai $\hat{\mathrm{S}}(\mathrm{n} \backslash \mathrm{n}), \hat{\mathrm{S}}(\mathrm{n} \backslash \mathrm{n}-1)$ adalah satu langkah prediksi dari $\mathrm{P}(\mathrm{n}), \mathrm{M}(\mathrm{n} \backslash \mathrm{n}-1)$ adalah satu langkah prediksi minimum MSE pada saat $n$, dan M(n\n) adalah MMSE pada saat $n$. $\mathrm{K}(\mathrm{n})$ adalah gain Kalman.

Tabel 3.1 Algoritma Filter Kalman

\begin{tabular}{|l|l|}
\hline \multicolumn{1}{|c|}{ Rumusan } & Keterangan \\
\hline \begin{tabular}{rl|}
$\hat{\mathrm{S}}(\mathrm{n} \mid \mathrm{n}-1)=a^{2} \quad \hat{\mathrm{S}}(\mathrm{n}-1 \mid \mathrm{n}-1)$ & $\begin{array}{l}\text { Prediksi } \\
\text { Filtering }\end{array}$ \\
\hline $\mathrm{M} \mid \mathrm{n}-1)=\mathrm{E}\left[(\mathrm{S}(\mathrm{n})-\hat{\mathrm{S}}(\mathrm{n}-1 \mid \mathrm{n}-1))^{2}\right]$ & $a^{2} \mathrm{M}(\mathrm{n}-1 \mid \mathrm{n}-1)+\sigma_{\phi}^{2}$
\end{tabular} & $\begin{array}{l}\text { Prediksi } \\
\text { Minimum } \\
\text { MSE }\end{array}$ \\
\hline$K(n)=\frac{M(n \mid n-1)}{\sigma_{n}^{2}+M(n \mid n-1)}$ & $\begin{array}{l}\text { Gain filter } \\
\text { Kalman }\end{array}$ \\
\hline$\hat{S}(n \mid n)=\hat{S}(n \mid n-1)+K(n)(P(n)-\hat{S}(n \mid n-1))$ & Filtering \\
\hline$M(n \mid n)=E\left[(S(n)-\hat{S}(n \mid n))^{2}\right]=(1-K(n)) M(n \mid n-1)$ & $\begin{array}{l}\text { Minimum } \\
\text { MSE }\end{array}$ \\
\hline
\end{tabular}

Dimana bentuk yang mendekati dari P(n) dalam table 3.1 berdasar statistik orde kedua adalah sebagai berikut

$$
\begin{aligned}
& r_{P}\left(m T_{S}\right)=E\left[P\left(n T_{S}\right) P\left(n T_{S}+m T_{S}\right)\right] \\
& \ldots \ldots \ldots \ldots=c_{H}\left(m T_{S}\right)+\left(\bar{H}+\mu_{S}\right)^{2}+\sigma_{S}^{2} \exp \left(-v m T_{S} / X_{c}\right)
\end{aligned}
$$

Parameter $\sigma_{\mathrm{H}}$ diberikan dalam bagian II dapat di hitung sebelumnya dan $\sigma_{\phi}^{2}=\left(1-a^{2}\right) \sigma_{S}^{2}$. Kita asumsikan bahwa variasi kanal adalah yang paling utama dikarenakan perubahan kecepatan pergerakan $\mathrm{v}$ dan jarak korelasi $\mathrm{X}_{\mathrm{c},}$ maka hanya variasi dari $a$ yang dipertimbangkan

Dengan mengikuti model yang sama yaitu AR(1), untuk LSE (Least Square Error) filter Kalman dari MSEnya adalah sebagai berikut

$$
E[L S E]=\frac{1}{L} E\left[\sum_{n=1}^{L}(S(n)-\hat{S}(n \mid n))^{2}\right]=\frac{1}{L} \sum_{n=1}^{L} M(n \mid n)
$$

Dalam keadaan stationer, bentuk Filter Kalman secara teori diperoleh saat $\mathrm{M}(\mathrm{n} \backslash \mathrm{n}) \rightarrow$ $\mathrm{M}(\infty)$ untuk $\mathrm{L}$ mendekati $\infty$ dimana untuk $\mathrm{M}(\infty)$ diperoleh sebagai berikut

$$
\begin{aligned}
& \lim _{L \rightarrow \infty} E[L S E]=\lim _{L \rightarrow \infty} \frac{1}{L} \sum_{n=1}^{L} M(\infty) \\
& .=\sqrt{1-a^{2}} \frac{\sqrt{\left(1-a^{2}\right)\left(\sigma_{S}^{2}+\sigma_{H}^{2}\right)^{2}+4 a^{2} \sigma_{S}^{2} \sigma_{H}^{2}}-\left(\sqrt{1-a^{2}}\right)\left(\sigma_{S}^{2}+\sigma_{H}^{2}\right)}{2 a^{2}}
\end{aligned}
$$

\subsubsection{Proses Estimasi pada Estimator Filter Kalman}

Untuk proses estimasi filter Kalman dengan algoritma yang teringkas dalam table 3.1, dapat digambarkan seperti pada gambar 3.1. yaitu diagram alir filter Kalman.

Untuk mengetahui unjuk kerja filter Kalman, diambil sejumlah data mean square error, kemudian berdasarkan persamaan (3.3) diambil nilai rata-ratanya. 


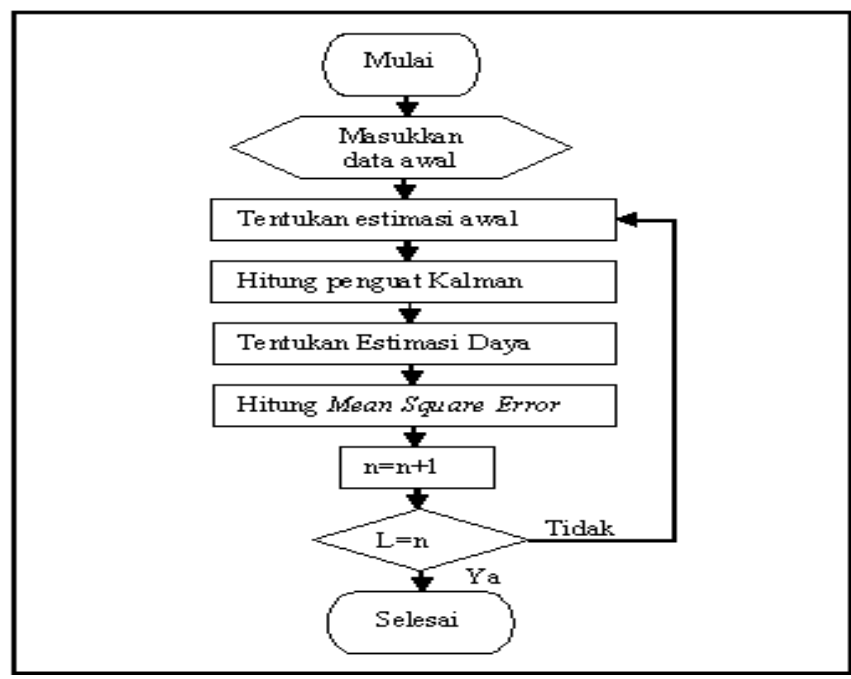

Gambar 3.1. Diagram alir Proses Estimasi Filter Kalman

dimana $\mathrm{L}$ adalah total sample.

Untuk estimator filter Kalman berdasarkan algoritma seperti table 3.1 dijelaskan sebagai berikut

Pertama-tama diketahui

$M(0 \mid 0)=\sigma_{S}^{2}=4^{2}=16$

$\sigma_{\phi}^{2}=\sigma_{S}^{2}\left(1-a^{2}\right)=16\left(1-0,9704^{2}\right)=0,9332$

$\sigma_{H}^{2}=c_{H}(0)=\left(\frac{10}{\ln 10}\right)^{2}\left(\frac{\pi}{6}\right)^{2}=31,0235$

Untuk $\mathrm{n}=1$ didapat MSE sebagai berikut

$M(1 \mid 0)=a^{2} M(0 \mid 0)+\sigma_{\phi}^{2}=0,9704^{2}(16)+0,9332=16$

$K(1)=\frac{M(1 \mid 0)}{\sigma_{H}^{2}+M(1 \mid 0)}=\frac{16}{31,0235+16}=0,34$

$M(1 \mid 1)=(1-K(1)) M(1 \mid 0)=(1-0,34) \cdot 16=10,5561$

untuk n selanjutnya mempunyai langkah yang sama dengan diatas dan LSE diperoleh sesuai persamaan (3.3)

\section{ANALISA HASIL ESTIMASI FILTER KALMAN}

\subsection{Pendahuluan} filtering.

Pada bab ini akan dibahas tentang persoalan estimasi yang salah satunya adalah sistem

Sebelum menganalisa filter kalman, akan dibahas bagaimana unjuk kerja estimator Sample Average. Unjuk kerja Sample Average secara teori diperoleh dari persamaan (3.1), untuk N yang tetap saat $\mathrm{T}_{\mathrm{S}} \rightarrow \infty$ maka $a \rightarrow$ nol dan $\mathrm{c}_{\mathrm{H}}\left(\mathrm{iT}_{\mathrm{s}}\right.$ ) akan sangat kecil sehingga persamaan (3.1) akan konvergen dengan limit mendekati harga

$$
\frac{N-1}{N} \sigma_{S}^{2}+\frac{c_{H}(0)}{N}
$$

Saat $\mathrm{N}=1$ persamaan (3.1) konvergen dengan nilai konstan $\mathrm{c}_{\mathrm{H}}(0)$ sama dengan $\sigma_{H}^{2}$ didapat kurang lebih 31 hal ini terlihat pada gambar 4.1, yang menggambarkan unjuk kerja estimator Sample Average dalam MSE sesuai persamaan (3.1) dengan $\mathrm{T}_{\mathrm{s}}$ dan $\mathrm{N}$ 


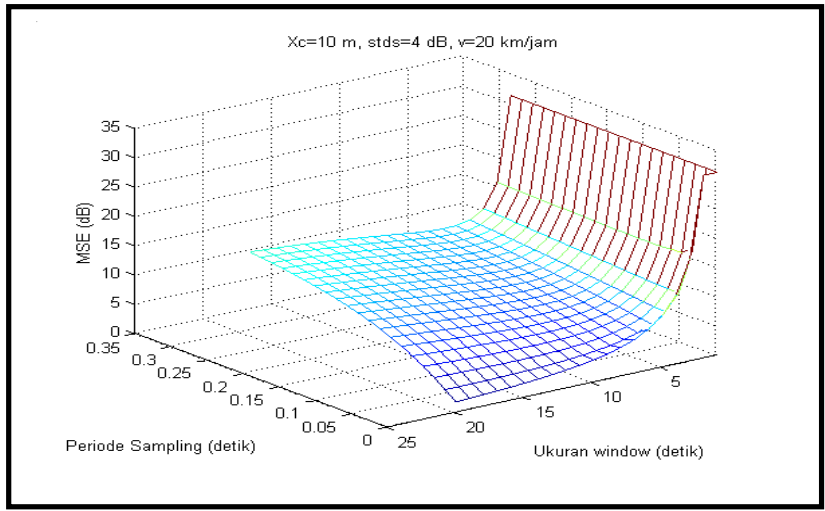

Gambar 4.1. Unjuk Kerja Sample Average dengan $\mathrm{T}_{\mathrm{s}}$ dan $\mathrm{N}$ pada daerah urban

\subsection{Perbandingan Filter Kalman dengan Sample Average}

Pada sub bagian ini akan dianalisa untuk daerah urban dan suburban. Berdasarkan persamaan (3.1) untuk estimator Sample Average secara teori, persamaan (3.4) untuk estimator filter Kalman secara teori dan estimator filter Kalman berdasarkan algoritma dengan perhitungan yang telah diulas diatas diperoleh grafik seperti gambar 4.2. untuk perbandingan pada daerah urban

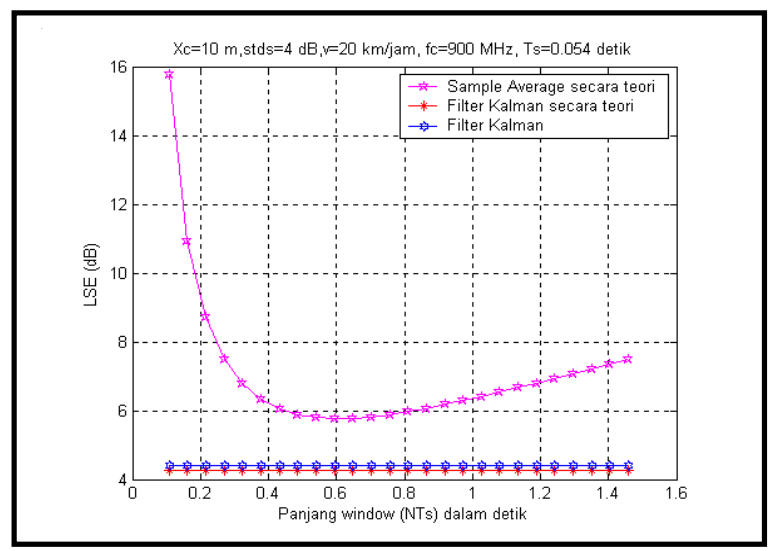

Gambar 4.2. Perbandingan unjuk kerja dalam daerah urban dengan $\mathrm{T}_{\mathrm{s}}$ yang besar

Dari perhitungan grafik diatas diperoleh LSE untuk estimator Sample Average saat $\mathrm{N}=2 \rightarrow \mathrm{LSE}=15,7684$ dan $\mathrm{N}=27 \rightarrow \mathrm{LSE}=7,4779$. Sedangkan untuk filter Kalman secara teori diperoleh $\mathrm{LSE}=4,2741$ dan berdasar algoritma diperoleh $\mathrm{LSE}=4,4058$ dimana nilai terlihat mendekati nilai secara teorinya. Dari grafik tersebut terlihat unjuk kerja filter Kalman lebih baik dibanding Sample Average yang mana terlihat bertambah baik dengan meningkatnya ukuran window dari $\mathrm{N}=2 \sim 11$ dengan LSE terkecil 5,765 kemudian menurun saat $\mathrm{N}=12 \rightarrow \mathrm{LSE}=5,7772$ dan makin menurun dengan bertambahnya ukuran window.

Kemudian untuk daerah suburban diperoleh grafik seperti gambar dibawah 


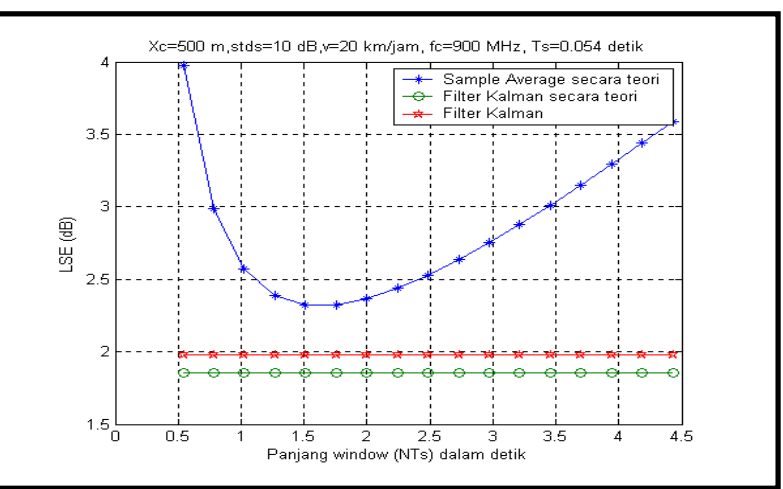

Gambar 4.3. Perbandingan unjuk kerja dalam dearah Suburban dengan $\mathrm{T}_{\mathrm{s}}$ yang besar

Dengan $\mathrm{X}_{\mathrm{c}}$ yang lebih besar membuat proses Shadow $\mathrm{S}(\mathrm{n})$ tampak lebih konstan karena $\boldsymbol{a}$ menjadi mendekati 1, sehingga pada awalnya unjuk kerja Sample Average meningkat (bertambah baik) seiring dengan bertambahnya ukuran window dan hal ini terjadi dalam range yang lebih lebar yaitu sampai $\mathrm{N}=27$. Karena proses Shadow bervariasi pada akhirnya unjuk kerja akan memburuk ketika ukuran window melebihi nilai tertentu $(\mathrm{N}>27)$. Sedangkan unjuk kerja filter Kalman masih lebih baik dibanding daerah urban.

Untuk $\mathrm{T}_{\mathrm{s}}$ yang kecil yaitu 0,01 detik pada daerah urban diperoleh grafik seperti dibawah

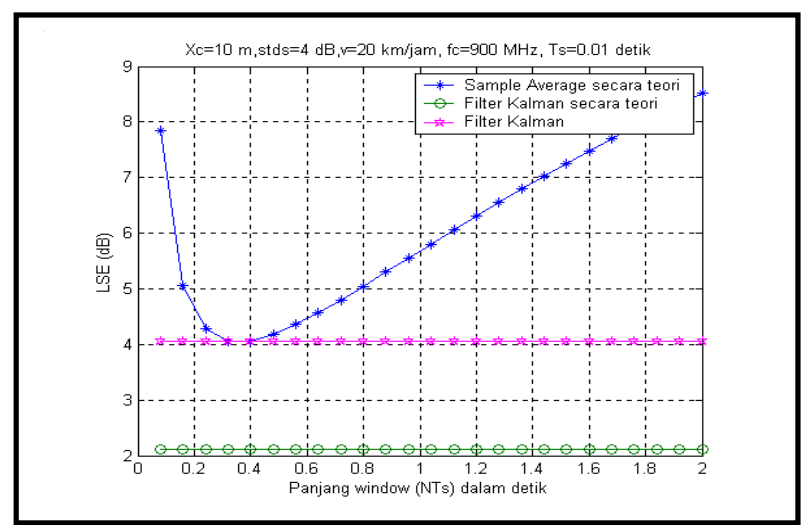

Gambar 4.4. Perbandingan unjuk kerja dalam daerah urban dengan $\mathrm{T}_{\mathrm{s}}$ yang kecil

Unjuk kerja filter Kalman secara teori berdasar persamaan (3.4) pada gambar 4.4 terlihat lebih baik dibanding unjuk kerja filer Kalman secara teori pada gambar 4.2 (yaitu dengan asumsi daerah yang sama tetapi dengan $\mathrm{T}_{\mathrm{s}}$ yang lebih besar). Dalam kenyataannya yaitu unjuk kerja berdasarkan algoritma terlihat berbeda secara signifikan dari teorinya. Sehingga dengan $\mathrm{T}_{\mathrm{s}}$ yang kecil filter Kalman secara teori tidak dapat memberikan estimasi LSE yang akurat, dan dari hasil estimasi menunjukkan bahwa estimator filter Kalman masih hampir selalu memberikan LSE yang minimum dibanding estimator Sample Average.

\subsection{Estimasi Daya dengan Mempertimbangkan Kecepatan Mobile Station}

Estimasi filter Kalman dengan dengan mempertimbangkan kecepatan mobile station dalam daerah urban digambarkan bahwa perubahan nilai a hanya dipengaruhi oleh perubahan kecepatan mobile station yang bergerak dalam hal ini antara $20 \mathrm{Km} l j a m$ sampai $80 \mathrm{Km} / \mathrm{jam}$.

Pada $\mathrm{T}_{\mathrm{s}}$ yang kecil yaitu 0,01 detik, dengan kecepatan antara $20 \sim 80 \mathrm{Km} / \mathrm{jam}$ diperoleh nilai $a$ antara $0,9945 \sim 0,9780$ sehingga terlihat bahwa nilai $a$ bervariasi hanya $2 \%$ dari nilai $a$ yang terkecil. Pada $\mathrm{T}_{\mathrm{s}}$ yang besar yaitu 0,1 detik dengan asumsi yang sama diperoleh nilai $a$ antara $0,9460 \sim 0,8007$ sehingga terlihat bahwa nilai $a$ bervariasi $18 \%$, nilai ini terlihat lebih besar dari saat $\mathrm{T}_{\mathrm{s}}=0,01$ detik.

Untuk filter Kalman dengan periode sampling kecil dan periode sampling besar yang tanpa mempertimbangkan kecepatan mobile station, nilai $a$ diperoleh dari rata-rata pada range $a$. Sehingga diperoleh gambar 4.5 dengan $\mathrm{LSE}=7,3581$ untuk unjuk kerja filter Kalman dengan mempertimbangkan kecepatan dan LSE=7,3779 untuk yang tanpa mempertimbangkan kecepatan. $\mathrm{Jika}_{\mathrm{s}}$ yang lebih kecil tanpa mempertimbangkan kecepatan diperoleh LSE=4,1526. 
Dan dapat diamati bahwa unjuk kerja estimasi filter Kalman dengan dan tanpa mempertimbangkan kecepatan mobile station dengan periode sampling yang sama yaitu $\mathrm{T}_{\mathrm{s}}=0,1$ detik terlihat unjuk kerja dengan mempertimbangkan kecepatan mobile station hanya sedikit lebih baik sekitar $0.3 \%$ dibanding tanpa mempertimbangkan kecepatan mobile station

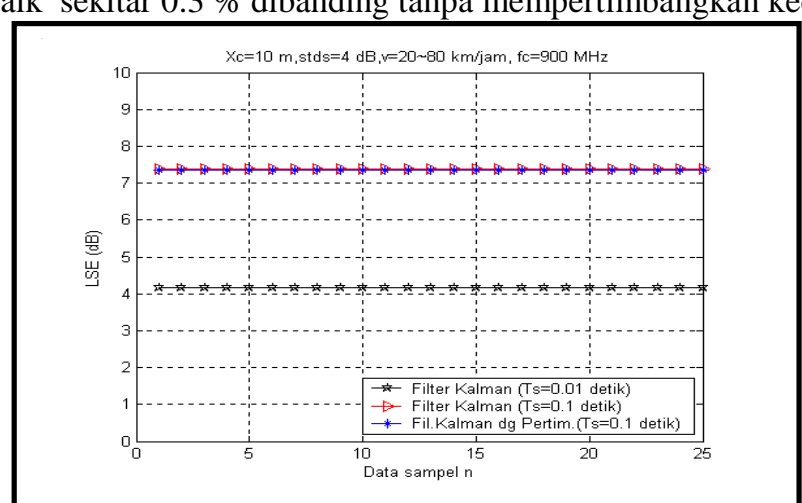

Gambar 4.5. Perbandingan unjuk kerja filter Kalman dengan mempertimbangkan kecepatan pada mobile station

\subsection{Perbandingan Unjuk Kerja Filter Kalman dan Sample Average dengan $\mathrm{T}_{\mathrm{s}}$ yang Sangat \\ Kecil}

Sejauh ini perbandingan unjuk kerja kedua estimator yaitu filter Kalman dan Sample Average dengan periode sampling tidak begitu kecil. Secara teori dapat diketahui unjuk kerja LSE dari filter Kalman dapat menjadi lebih baik dan lebih baik lagi saat $\mathrm{T}_{\mathrm{s}}$ menjadi lebih kecil dan lebih kecil lagi. Tetapi tidak begitu jika berdasarkan algoritma seperti terlihat pada gambar 4.6.

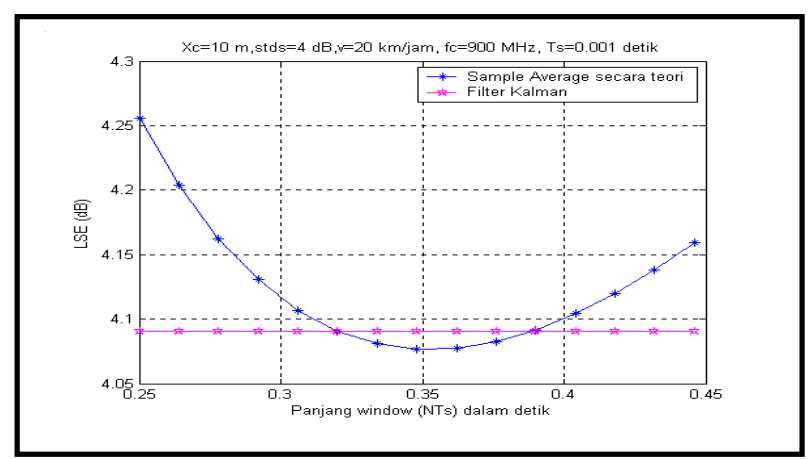

Gambar 4.6. Perbandingan Unjuk kerja dengan periode sampling sangat kecil

Grafik diatas menunjukkan bahwa dengan periode sampling yang sangat rendah yaitu 0,001 detik filter Kalman memberikan LSE yang sedikit buruk dibandingkan dengan unjuk kerja LSE terbaik yang dicapai oleh estimator Sample Average. Hal ini dikarenakan saat $\mathrm{T}_{\mathrm{s}}$ beranjak turun drastis, korelasi antar sample Multipath $\mathrm{H}(\mathrm{n})$ ikut diperhitungkan. Koefisien korelasi ditentukan oleh kovarian $\mathrm{H}(\mathrm{n})$ pada saat periode sampling tersebut dibagi oleh varian dari $\mathrm{H}(\mathrm{n})$, sehingga diperoleh saat $\mathrm{T}_{\mathrm{s}}=0,1$ detik koefisien korelasi antar sample $\mathrm{H}(\mathrm{n})$ kurang dari 0,1 , padahal ketika $\mathrm{T}_{\mathrm{s}}=0,01$ detik koefisien korelasi kira-kira 0,4. Nilai ini akan bertambah sampai 0,9794 ketika $\mathrm{T}_{\mathrm{s}}=0,001$ detik yang mengakibatkan filter Kalman sangat terganggu karena tingginya korelasi $\mathrm{H}(\mathrm{n})$.

\section{PENUTUP}

\subsection{Kesimpulan}

1. Dengan filter Kalman, didapat estimasi daya pada komunikasi bergerak dengan error yang hampir selalu memberikan nilai yang paling kecil, dibanding estimator Sample Average.

2. Dengan memperhitungkan variasi kecepatan mobile station dalam algoritma filter Kalman, hanya sedikit berpengaruh dalam memperbaiki unjuk kerja dari estimator filter Kalman dibanding tanpa memperhitungkan variasi kecepatan.

3. Unjuk kerja dari estimator filter Kalman akan lebih jelek dari estimator Sample Average pada daerah tertentu dengan mengambil waktu sampling terlalu kecil yaitu $\mathrm{T}_{\mathrm{s}}=0,001$ detik, Ini 
terjadi karena proses Multipath yang diasumsikan tidak berkorelasi akan menjadi berkorelasi dengan kecilnya waktu sampling.

\subsection{Saran}

1. Pembuatan simulasi dari daya terima yang dapat dibandingkan berdasar pengukuran.

2. Dengan data secara simulasi dan real dapat dibuktikan keakuratan filter Kalman dalam memprediksikan daya terima pada sistem komunikasi bergerak.

\section{DAFTAR PUSTAKA}

Ismail, Nashrudin. (1998). Kanal Rayleigh Fading pada Komunikasi CDMA. Elektro Indonesia. edisi ke-12, Maret 1998

S., M., Kay. (1993). Fundamentals of Statistical Signal Processing. EnglewoodCliffs. NJ: Prentice-Hall. vol. 1.

Tao, Jiang. Nicholas, D., Sidiropoulos and Giorgios, B., Giannakis. (2003). Kalman filtering for power in mobile communications. IEEE Transaction on Wireless communications, vol.2, no.1, Januari 2003 